\title{
The Status of African American Faculty Members in English
}

Doug Steward

ADE Bulletin 140 (Fall 2006), pp. 32-34

ISSN: 0001-0898

CrossRef DOI: 10.1632/ade.140.32

Copyright @ 2006 by The Association of Departments of English

All material published by the The Association of Departments of English in any medium is protected by copyright. Users may link to the ADE Web page freely and may quote from ADE publications as allowed by the doctrine of fair use. Written permission is required for any other reproduction of material from any ADE publication.

Send requests for permission to reprint material to the ADE permissions manager by mail (26 Broadway, New York, NY 10004-1789), e-mail (permissions@mla.org), or fax (646 458-0030). 


\title{
The Status of African American Faculty Members in English
}

\author{
DOUG STEWARD
}

\section{AM privileged to be at} CLA this year to address a topic of pressing but long-standing concern to many in the higher education community: the disproportionately low number of African American faculty members in English. To address this topic, the Executive Committee of the Association of Departments of English has appointed an Ad Hoc Committee on the Status of African American Faculty Members in English, including as members Robyn Warhol (the chair), Valerie Lee, Paula Krebs, and this panel's own Dolan Hubbard, who has over the years done a great deal for the ADE community. The committee's work is organized around the question, "How can English departments and their faculties improve the pathways by which African Americans are invited to enter and remain in the profession of English studies?" The committee will report on its work and offer practical recommendations to chairs of English departments, and you can look for the report next year in the ADE Bulletin. I'd like to give you now an overview of the committee's work thus far.

In preparation for the committee's work, the $\mathrm{ADE}$ compiled some data that might be useful in introducing my fellow panelists' comments, and I've distributed a few of these. I'll go over them quickly:

- Of the United States population, $12 \%$ to $13 \%$ report themselves as black or African American (2004 Amer. Community Survey).

- Fewer than $4 \%$ of tenured faculty members at the rank of full professor in all disciplines in degreegranting, Title-IV participating, not-for-profit domestic institutions are African Americans (Natl. Study of Postsecondary Faculty [NSOPF]; 2004).

- About $6 \%$ of full-time tenured faculty members in English are African American, while about 5\% of full-time tenured faculty members in all other disciplines are African American (NSOPF; 2004).
- About $10 \%$ of full-time tenure-track faculty members in English are African American, while about $7.5 \%$ of full-time tenure-track faculty members in all other disciplines are African American (NSOPF; 2004).

- In the fall of 2001, around 59\% of all faculty members at Historically Black Colleges and Universities (HBCUs) were African American, while "only $3.6 \%$ of the total full-time faculty at the nation's 25 highest-ranked universities” were African American ("Racially Diverse").

- Of the 35 institutions producing seven or more African American BAs going on for $\mathrm{PhDs}$ in English in the thirty-one-year period 1973 to 2003, about half (eighteen) are HBCUs (Survey of Earned Doctorates [SED]).

- Of the approximately 400 institutions that have graduated African American undergraduates who have gone on to complete a $\mathrm{PhD}$ in English, 178 produced only one in the past thirtyone years (SED).

- From 1973 to 2003, 2.4\% of the more than 49,000 doctorates in English and literature were earned by African Americans; in all disciplines the figure was $3.7 \%$ of nearly 1.3 million doctoral degree recipients over the same thirty-one years (SED).

These numbers, indexing social and educational realities, show that the situation of African American faculty members looks quite different depend-

The author is associate director of MLA English Programs and the ADE. A version of the article was delivered at the 2006 College Language Association Convention in Birmingham.

ADE Bulletin, No. I40, Fall 2006

(C) 2006 BY THE ASSOCIATION OF DEPARTMENTS OF ENGLiSH 
ing on exactly how one asks questions of the data. The numbers do not tell us which lived realities are indexed, who the individuals were who earned or did not earn the degrees, or who their mentors were or could have been-in other words, they do not tell us much about the pathways by which black Americans enter and succeed in, or walk away from, advanced study in English. What stories lie behind the data? What stories do the data not index? What other data do we need in order to make effective arguments in departments and to administrations for improving the pathways to faculty careers in English? I pose these questions to you because English departments at HBCUs play a very special role in producing future English professors, and I am mindful that the generalizations I will make do not, by and large, apply to departments at HBCUs.

There is so much to say on the little that has been documented about those pathways, it's difficult to know where to begin-especially since it's not my place to preach to a choir that knows the hymnal better than I do. I'll simply mention a few of the resources the ADE ad hoc committee has found most useful and some of the topics that strike me, based on the research that the committee has done, as especially pertinent and ask those present to say which topics they consider most important. Along the way, I'll also pose some questions for the other panelists and for audience members, whose input I think the ad hoc committee would be grateful to have.

The pathways leading to faculty careers in English do not begin at the undergraduate level, much less the graduate level. In their book Increasing Faculty Diversity, Stephen Cole and Elinor Barber address this issue in a rigorous fashion under the usual rubric "the pipeline," and I recommend the book with the caveat that its focus on elite institutions limits its specific applicability and sometimes skews the authors' views. Under the less mechanistic rubric "pathways," Clifford Adelman also addresses the issue commonly known as the pipeline in an important study titled The Toolbox Revisited, which I also recommend.

I'm afraid that members of English faculties are reluctant to take into account that there is no future faculty in English if English education at the lower levels does not thrive. If the No Child Left Behind legislation does no other good, I hope that it will prompt English departments to take a more serious and active interest in their role as produc- ers of the nation's English educators in secondary schools. If the pathways to successful faculty careers in English stretch back to education before college, how can those in the higher education community contribute to improving those pathways at the secondary level, especially where students of color are concerned?

It appears that graduate English departments across the country are making good-faith efforts to increase the number of black graduate students in their programs. The directors of graduate study with whom I've spoken often express frustration with their lack of success and dismay at institutional barriers to targeting students of color.

On the other hand-and I am pointedly not talking about a department such as Dr. Harper'sit is not clear to me that most English departments are making an effort to increase the number of African Americans who major in English as undergraduates. My thoughts on this issue are tentative and based more on common sense and hearsay than research, but it seems to me that if English departments of all types do not increase the number of African Americans in the undergraduate major, then graduate programs will continue to compete for a small number of black applicants. Given the economy of prestige that governs higher education, they will also compete primarily for an even smaller number of those applicants, overlooking applicants from less prestigious undergraduate institutions. How can English departments at various types of institutions attract the attention of African American undergraduates and increase the appeal of the English major to them?

Once in graduate school, on the job market, or in a tenure-track faculty position, African Americans face an array of challenges on top of the usual ones, challenges that their white counterparts by and large do not. William Banks and Joseph Jewell have argued, for instance, "When, in the face of constraints and pressure, Black intellectuals particularize their interests and energies, they deviate from one of the governing tenets of Western intellectual life" (84)-universalism. This tension between particular (or subjective) and universal (or objective) — we might want to put all those terms in scare quotes-may shed light on why some white administrators view specifically African American scholarship with suspicion. On the flip side of this coin, black graduate students and faculty members may find that they are pressured 
into African American studies rather than an area they prefer, such as British Romanticism, or even that they are taken seriously only in African American studies. On the job market and in tenure and promotion proceedings, job applicants and faculty members of color may find that their color and qualifications are conflated-that is, that they are assumed to be qualified because of their color or that they are assumed to be unqualified, an affirmative action token, because of their color. Graduate students of color tell me that hiring committees express particular skepticism about their ability to teach general survey courses.

Departments at historically white institutions should be mindful, too, that an insidious and damaging resentment may exist among white graduate students or faculty members when special packages or hires have, in good faith, been made available by departments in order to attract black graduate students or faculty members. Efforts to increase the representation of students and faculty members of color on committees and task forces may also have the unintended consequence of overloading the limited number of such people with committee work that prevents them from devoting due attention to research and teaching.

These are all discriminatory practices from above-graduate professors, more-senior colleagues, department chairs, upper administrators. The MLA Committee on the Literatures of People of Color has lately taken an interest in institutionalized discrimination from below: student evaluations that do not adequately gauge negative student reactions to professors of color when those reactions are motivated by students' overt or covert racism or by an unwillingness on students' part to engage the subject matter of ethnic studies.

This array of seemingly intractable issues is dispiriting to many and diminishes African Americans' chances of success-and their desire to succeed-as faculty members in English. The ADE ad hoc committee is eager to hear which of these or other issues are most pressing and how it and the ADE community at large can address them practically and consequentially.

Finally, I would like to draw your attention to two documents. The first is a brochure produced by the MLA Committee on the Literatures of
People of Color and endorsed by the MLA Executive Council: Guidelines for Good Practice. The brochure is intended for distribution to tenure and promotion committees, department chairs, and upper administrators in order to highlight the biases and practices that challenge graduate students and faculty members of color. The committee has heard from many that the brochure is useful. The second document is a report by Ann Springer, associate legal counsel for the American Association of University Professors, that addresses in detail the 2003 Supreme Court decisions involving the University of Michigan that altered the permissible parameters of programs geared toward underrepresented groups. Springer's legal recommendations serve as a sweeping summary of the thorny challenges in improving the status of faculty members of color.

I look forward to hearing from my fellow panelists and from the audience on these and other questions. Thank you.

\section{Works Cited}

Adelman, Clifford. The Toolbox Revisited: Paths to Degree Completion from High School through College. US Dept. of Educ. Feb. 2006. 21 Feb. 2006 <www.ed.gov/rschstat/ research/pubs/toolboxrevisit/index.html $>$.

Banks, William M., and Joseph Jewell. "Intellectuals and the Persisting Significance of Race." Journal of Negro Education 64.1 (1995): 75-86.

Cole, Stephen, and Elinor Barber, with Melissa Bolyard and Annulla Linders. Increasing Faculty Diversity: The Occupational Choices of High-Achieving Minority Students. Cambridge: Harvard UP, 2003.

Committee on the Literatures of People of Color in the United States and Canada. "Guidelines for Good Practice.” ADE Bulletin 132 (2002): 90-92. <www.mla .org>.

National Study of Postsecondary Faculty (NSOPF). Data Analysis System. Natl. Center for Educ. Statistics. 27 Mar. 2006 <nces.ed.gov/dasol/tables>. Path: Postsecondary Faculty.

“The Racially Diverse Faculties at America's Black Colleges." Journal of Blacks in Higher Education 45 (2004): 76.

Springer, Ann D. How to Diversify Faculty: The Current Legal Landscape. AAUP. July 2004. 23 Feb. $2006<$ www .aaup.org/Legal/info\%20outlines/legaa.htm>.

Survey of Earned Doctorates (SED). WebCASPAR: Integrated Science and Engineering Resources Data System. 25 Aug. $2005<$ webcaspar.nsf.gov>.

2004 American Community Survey. American FactFinder. US Census Bureau. 24 Apr. $2006<$ factfinder.census.gov>. 